\title{
A possible case of encephalitis due to H1N1 infection
}

\author{
Seneviratne NHG, Pathirana KD, Bodinayaka CK \\ Professorial Medical Unit, Teaching Hospital Karapitiya, Galle, Sri Lanka \\ Correspondence: Dr.N.H.G. Seneviratne (nadeejaseneviratne@yahoo.com)
}

\section{Introduction}

A new entrant novel H1N1 influenza A virus has already been acquired world wide attention. Globally 15174 deaths have been reported among confirmed H1N1 cases up to February 2010 (1). There were 642 confirmed cases and 48 deaths reported in Sri Lanka due to H1N1 influenza by April 2010 since first reported in June 2009 (2).

Complications expected with this novel infection is similar to seasonal influenza infection viz; exacerbations of underlying chronic infections, respiratory tract infections (otitis media, sinusitis, pneumonia), neurological illnesses (encephalitis, encephalopathy, febrile seizures and status epilepticus), rhabdomyolysis, pericarditis, myocarditis and sepsis $(3,4)$.

Encephalitis as a neurological sequel of H1N1 influenza was first reported in Texas during the last epidemic (5). Main causative agents of encephalitis reported in Sri Lanka are Japanese B encephalitis virus, herpes simplex virus (type 1 ) and rabies virus whereas seasonal influenza A and B causing fatal encephalitis are not reported. 


\section{Case Report}

A 17-year old boy without any previous illness, presented to a general practitioner with cough, cold, fever and headache of two days. Fever subsided with symptomatic treatment but headache persisted. He was admitted to General Hospital Matara with generalized tonic clonic seizures lasting 45 minutes, with frothing and incontinence of urine on the $7^{\text {th }}$ day of illness. He was treated with intravenous acyclovir, intravenous cefotaxime and antiepileptic drugs for six days. Cerebro-spinal fluid (CSF) revealed 03 lymphocytes but no polymorphs or red cells. CSF protein was $30 \mathrm{mg} / \mathrm{dL}$ while sugar was $82 \mathrm{mg} / \mathrm{dL}$. CSF fluid was negative for Herpes Simplex and Japanese B encephalitis virology. Non- contrast CT scan of brain was normal and EEG showed generalized slow waves.

On $7^{\text {th }}$ day he was transferred to Teaching Hospital Karapitiya for an urgent MRI scan of brain. On admission he was febrile and sedated. In the ward phenytoin sodium $18 \mathrm{mg} / \mathrm{kg}$ infusion, sodium valproate $200 \mathrm{mg}$ twice daily, phenobarbitone 10 $\mathrm{mg} / \mathrm{kg}$ infusion and diazepam (IV) $5 \mathrm{mg}$ bolus over 1 min were instituted as he developed repeated generalized tonic-clonic seizures.

Throat and nasal swabs were taken for H1N1 influenza virology on next day ( $15^{\text {th }}$ day of illness). As real time polymerase chain reaction for H1N1 influenza virus became positive, oseltemivire $75 \mathrm{mg}$ twice daily was given for 5 days. Patient developed repeated myoclonic jerks two weeks following admission to Karapitiya and clonazepam was introduced.

There was a dramatic improvement over the next few days. He was free of seizures and no focal neurological deficit was detected at discharge. He was back in school one month following discharge. During first four months of follow-up he had two attacks of generalized tonic clonic seizures, possibly due to poor compliance. Meanwhile some deterioration in his behaviour and school performances was noted.

\section{Investigations}

Full blood count was normal initially but later showed mild neutrophil leucocytosis. Serum Na, K and blood urea remained within the normal limits. Serum calcium and $\mathrm{Mg}$ levels were within the normal range at the beginning of illness.
C-reactive protein was between 1.2 to $3.1 \mathrm{mg} / \mathrm{dL}$ (normal $<0.8$ ) during the illness. ECG showed sinus tachycardia while his chest radiography and echocardiography did not show any abnormalities.

EEG done during the illness showed generalised asymmetrical slow waves with occasional sharp waves which were initially thought to be due to herpes simplex encephalitis. Subsequent EEGs showed less slow waves and it became normal two months after discharge. MRI scan of the brain was normal except for the evidence of sinusitis in maxillary, ethmoid and frontal sinuses

\section{Discussion}

This 17-year old boy developed seizures and impaired level of consciousness, seven days following influenza like illness. Possible differential diagnosis included viral encephalitis, post-viral encephalopathy like acute disseminated encephalomyelitis or metabolic derangement. His CSF serology was negative for common viruses that cause encephalitis in Sri Lanka. During the early phase of illness renal and liver functions and serum electrolytes including $\mathrm{Ca}, \mathrm{Mg}, \mathrm{Na}$ and $\mathrm{K}$ were normal. EEG showed generalised slow waves compatible with encephalitic illness and neuroimaging did not show any features suggestive of Herpes Simplex encephalitis.

Our patient had many similarities to four similar cases reported in Texas (5). All of them were males between $10-17 \mathrm{yrs}$ and had influenza-like illness with seizures. In those cases encephalitis has been confirmed based on EEG changes of background slow waves. Three patients had sinusitis on imaging, similar to our case. All had positive H1N1 influenza virus in respiratory tract specimens and no other cause for encephalitis was found. However in our patient antigen test was done only on the $15^{\text {th }}$ day of the illness and the possibility of nosocomial infection from $\mathrm{H} 1 \mathrm{~N} 1$ virus cannot be totally excluded. The fact that the seizures resistant to a combination of antiepileptics later subsided following anti- H1N1 therapy raises the possibility that this infection may be responsible for his clinical status.

We suggest that H1N1 influenza A infection should also be considered in patients with encephalitic illness associated with influenza-like illness, specially during an epidemic of H1N1 infections. 
By maintaining vigilance, we hope, more cases will be detected during future epidemics to confirm this association.

\section{References}

1. World Health Organization Current WHO phase of pandemic alert. World Health Organization web site. http:/www.who.int/csr/don/2010_02_5/en/index.html (last date accessed; $5^{\text {th }}$ February 2010).

2. Epidemiology Unit web site, Sri Lanka. Pandemic H1N12009 - Sri Lanka, www.searo.who.int/en/Section10/ Section2562_15045.htm (last date accessed; 19 $9^{\text {th }}$ April 2010).
3. Sullivan SJ, Jacobson RM, Dowdle WR, Poland GA. 2009 H1N1 influenza mayo clin Proc. 2010; 85: 64-76.

4. Writing Committee of the WHO Consultation on Clinical Aspects of Pandemic (H1N1) 2009 Influenza. Clinical Aspects of Pandemic 2009 Influenza A (H1N1) Virus Infection, NEJM362: 1708-19.

5. Centre for Disease Control \& Prevention, Neurological complications associated with Novel H1N1 influenza A virus infection in children. MMWR Morb Mortal Wkly Rep 2009; 58; 773-8. 